\title{
Motives Involved in the Processes of Mergers in Credit Unions: A Study in Minas Gerais, Brazil
}

\author{
Wendel Silva ${ }^{1}$, Juliana Ramires ${ }^{1}$, Alfredo Melo ${ }^{1} \&$ Aleixina Andalécio ${ }^{1}$ \\ ${ }^{1}$ Master in Management, Faculdade Novos Horizontes, Brazil \\ Correspondence: Wendel Silva, Faculdade Novos Horizontes, Rua Alvarenga Peixoto, 1270. 31.180-121, Belo \\ Horizonte, MG. Brazil. E-mail: wendel.silva@unihorizontes.br
}

Received: October 11, 2013

Accepted: October 31, 2013

Online Published: November 22, 2013

doi: 10.5539/ibr.v6n12p95

URL: http://dx.doi.org/10.5539/ibr.v6n12p95

\begin{abstract}
This study aims to identify the reasons that led credit unions in the State of Minas Gerais, Brazil, to carry out processes of incorporation, based on the motives included in the theory of the firm and the agency theory: asymmetrical expectations, compensation and tax incentives, replacement costs and market values, seek for economies of scale, anticompetitive effects and pursuit of monopoly power and reducing the risk of insolvency. We investigated four credit unions that have undergone processes of mergers from 2008 to 2011, by interviewing six managers who participated in the processes of incorporation. Compensation and tax incentives, anticompetitive effects and pursuit of monopoly power were not motivating factors, but we identified the seek for economies of scale as a motivation in all the cooperatives studied. We observed that the cooperative has an organizational structure distinct from other kinds of business, but there is a similarity in their merging processes, because the underlying reasons inserted in the theory of the firm and the agency theory were identified as triggers for the mergers.
\end{abstract}

Keywords: credit unions, theory of the firm, agency theory, incorporation, merger

\section{Introduction}

In today's society, the cooperative movement has been seeking ever more growth through mergers. Goddard, McKillop and Wilson (2009) report that recent years have witnessed a wave of consolidation amongst USA credit unions: around $3 \%$ of the total population of CUs have disappeared annually over the past 10 years. These authors present data to corroborate this assertion: they were 23,866 CUs in 1969; 10,628 in 1999 and 8,372 in 2006.

Jack Brick, CEO of Brick \& Associates, Inc., reports that the USA loose 350 credit unions per year, mostly to mergers, and that clearly affects the market base of corporate credit unions, since the corporate CUs that serve them need also to merge to maintain competitiveness (Gilpatrick, 2007).

In Brazil, the merger and incorporation processes first began in the 1990s, with the support of the Privatization National Plan and the inflow of foreign capital, which led to private control of various sectors of the economy (Camara, 2007). Concerning cooperatives, about 35\% of them have been established here since the 1990s, and the economic stabilization, coupled with the inflation rate reduction and the decreasing of the banking loans spread, led them to restructure its business model and rearrange their geographic location (Trindade et al., 2008).

Credit unions are part of the National Financial System, developing the role of financial intermediation, aiming mainly to play a social role. They have a distinct legal personality established and regulated by the Cooperative Law 5,764/71.

According to Trindade et al. (2008), the cooperative credit system has been undergoing significant transformations, seeking economies of scale and efficiency in order to make it an alternative in a context of lower interest rates and increased competition in the loaning market.

To Andrade and Rossetti (2009), corporate changes are an internal factor that leads to a strategic realignment of corporations, including mergers and acquisitions. Veloso Júnior (2011) reports that, among the credit unions, the processes of mergers reveal a search for strengthening and their number grew from four in 2000 to 28 in 2010.

The literature shows several reasons for conducting mergers and acquisitions: asymmetric expectations, 
compensation and tax incentives; costs replacement and market values; pursuit of economies of scale (operational and managerial synergies); anticompetitive effects and pursuit of monopoly power, and reducing the risk of insolvency.

Credit unions seek strengthening processes that could promote their corporate and administrative equity restructuring. But there is no consensus in the literature regarding factors that influence the choice of such processes. In addition, the credit union in Brazil is a recent phenomenon that grows since 2000 (Veloso Júnior, 2011). Thus, it is necessary to research and think over the reasons for credit unions mergers.

We aimed to identify and analyze the reasons why four credit unions affiliated to the Central of Cooperatives of the State of Minas Gerais (Sicoob Cecremge) conducted processes of mergers, by: 1) characterizing the credit cooperatives in Brazil, emphasizing its trend toward merging; 2) describing the incorporation processes; 3) identifying the reasons for incorporation, and 4) relating the reasons identified to the theoretical framework of the theory of firm and the agency theory.

This work may contribute to the further development of the theme and increase the academic knowledge about the Brazilian cooperative credit system, as well as about the processes of mergers in these organizations and the development of future research related to the area of finance.

\section{Brazil's Cooperatives Consolidation and Merging}

Braga (2000) explains that the cooperative thought arose in Western Europe in the early nineteenth century, where many thinkers formed the cooperative doctrine, under the aegis of the ideals of justice and fraternity. Pinheiro (2010) points out that, in Brazil, the Banking Reform Law (Law 4.595/64) created the Central Bank of Brazil, which regulates and monitors the institutions of the financial system, including credit unions.

The Central Bank of Brazil has enacted regulatory provisions applicable to credit unions, and has sought their consolidation and growth within the financial system, so they could offer several services, such as catching and managing funds, provisioning of credit, and other financial services to their members. To consolidate the cooperatives' role in the business of credit, it was enacted the Law 130 of April 17, 2009, which brought to credit unions relevant changes on their operational management structure.

Camargos and Camargos (2010) report that mergers and acquisitions allow increasing size and market share, and create and consolidate corporate groups, changing the competition and the reality of companies in the market. From the perspective of Oliveira (1987), the merger of cooperatives is a current strong tendency. Then, it is necessary to adopt a series of preliminary measures of legal nature. Although the legal support for mergers and acquisitions is still Law 5.764/71, one must also pay attention to the Law of Corporations n. 6.404/76, which is closely linked to the targeting inherent to such proceedings.

\section{Previous Studies on Credit Unions Mergers and Acquisitions and Its Legal Implications}

We attempted to search studies that focused the process of mergers and acquisitions in credit unions. Among these, Lima (2008) aimed at examining the change of the performance indices after the transformation of the cooperatives into a free admission institution. As he reported, from the moment the cooperative becomes free admitting, a change in its performance occurs, depending on the possibilities of growth. He suggests applying other models of performance measurement to the cooperatives studied.

Borges (2009) sought to determine whether agglutination (incorporation) of credit unions has led to changes in the perception of value by its members. He found out that there was no change in the value perceived by its members, for the reasons that led to the process of 'assemblage' were related to the opening of new markets and to attracting new members, which were considered reasons of strategic nature, demonstrating that there was a distancing in perception from the cooperative members to the cooperative management. He points out that the agglutination process has brought significant changes to the cooperative incorporated. Veloso Júnior (2011) sought to identify the main impacts of mergers and incorporation on the financial performance of credit unions in Brazil, using a group of cooperatives that have undergone mergers or incorporation since 2000 and a group with no history of merger or incorporation processes, to assess whether there were statistically significant differences between the behaviors of the two groups.

On the legal aspect, Camargos (2008) states that in a merger a new firm may be created (consolidation), while in an acquisition one of the companies involved generally keeps its legal identity. In fact, to confer legitimacy to the process there is a set of explanations, derived mainly from the theory of the firm and the agency theory. According to this author, "the statement of reasons for mergers and acquisitions flows naturally from the origin, growth and evolution of the firm and the business activity" (Camargos, 2008). Hence arises the "modern corporation' concept, known today as 'corporation' (or joint-stock company), which considers mergers and 
acquisitions as opportunities for growth and to achieve the goal of maximizing the shareholders' wealth and the utility management, two streams of the theoretical framework of the theory of the firm.

According to Cano (2002), mergers and acquisitions growth is related to the economic growth and the development of the Brazilian capital market. Mergers and acquisitions and their socioeconomic consequences are currently increasing, and finance literature points out the existence of waves of mergers and acquisitions, which played an important role in the process of concentration of capital, asset restructuring and consolidation of some sectors of the economy.

\section{Motivations Underlying the Realization of Mergers and Acquisitions}

According to Coase (1937), there are specialized trades in an economy, so that the distribution of resources becomes organized by the price mechanism. He points out the emergence of the firm, which allocates production resources under the auspices of a businessman, in a less onerous way than the market, at the expense of existing transaction costs and having the division of labor as the reason of its existence (because that is a result of the increased complexity of work specialization). The firm's production and size would expand to the point where the marginal cost of performing an extra activity within the firm would be equal to its market price, which explains the occurrence of market transactions.

Alchian and Demsetz (1972) complement the theory of Coase (1937) by asserting that the transaction costs in the market are determined by the organization of the resources in a firm. These authors developed the theory of the firm, which is based on administration costs, in the sense that the lower the cost of administration, the greater the comparative advantage of organizing resources within a firm.

Coase (1937) lists factors that led to the growth of the size of the firm: "lower organizational costs and low growth, with an increase in the organized transactions; less likelihood of entrepreneurs make mistakes and the small increase in errors, with an increase of organized transactions; reduction in the price of production factors supplied to firms of larger sizes".

The standpoint of Jensen and Meckling (1976) is that the basic assumption underlying the agency theory is that large firms (corporations) are a set of contracts that aim to maximize the shareholders' wealth.

Nakamura (2005) argues, from the analysis of the reasons for merger and acquisition, that ultimately a profit-condition is the key for the decision-making process. Penrose (1959), when discussing the motivations underlying the actions of the firm, points out the existence of difficulties to determine the "immediate reason" behind the decisions made by the firms.

Andrade and Rossetti (2009) report that since the time when dispersion of the corporations' capital occurred, and, consequently, there was a separation between ownership and management, the agency theory arose as a development of the theory of the firm.

According to Camargos and Barbosa (2003), it is almost impossible to ensure that the agent makes the optimal decision. And the agency costs are the sum of the following costs: cost of monitoring the capital sum, cost of demonstration of the agent and the residual cost.

For Firth (1980), most of these reasons we analyze here are based on two theories of the firm. For the neoclassical theory of firm, profit maximization and competitive market forces motivate managers to make decisions that maximize the value of firms and the shareholders' wealth. For instance, firms will engage in takeovers if they are sure that this will result in increased shareholders (acquirers)' wealth resulting from the increase in profitability, whether by creation of monopoly power, either by synergy or even by the replacement of inefficient managers in the acquired firms.

The managerial utility maximization theory argues that, beyond a certain satisfactory level of profit, managers try to maximize their usefulness (which reduces the risk of losing their jobs, increases the level of their salaries, their empowerment and job satisfaction) in expense of maximizing shareholder's wealth. These objectives can be achieved by increasing the size of the firm, being the takeovers, in practice, the fastest way to achieve them. Instead of increasing the size or profitability, their most pursued goal is increasing the benefits for the managers.

Goddard, McKillop and Wilson (2009) examined the determinants for USA credit unions disappearance through liquidation or acquisition, during the period 2001-2006. They estimated competing risks and hazard functions for the probabilities of liquidation and acquisition and found a variety of factors that influence the hazard of disappearance, many of them also common in other sectors. Unique to credit unions, they found factors such as charter type and common bond categorization. As unique to credit unions, they found factors such as the type of charter and the common bond categorization. They also found a link between hazard of disappearance and 
technological capability: credit unions with no website were at the highest risk of acquisition. Hosono, Sakai and Tsuru (2006) investigated the motives and consequences of the consolidation of cooperative banks in Japan during the period 1984-2002. They reached three major findings: 1) less profitable and less cost-efficient banks are more likely to be an acquirer and a target, though even less profitable and less efficient banks are more likely to be a target rather than an acquirer. In addition, a larger bank is more likely to be an acquirer and a smaller one a target; 2) acquirer banks improved cost efficiency after the consolidation, but this did not contribute to sufficiently stabilize the local banking system despite the regulators' motive; 3) the consolidation tended to improve the profitability of merging banks when the difference in profitability and healthiness between acquirer and target banks was large.

Worthington (2004) used a two-stage procedure to evaluate the determinants of merger and acquisition (M\&A) activity in Australian credit unions over the period 1992/1993 to 1994/1995. Their results identified several significant influences on M\&A activity in Australian credit unions, like asset size and quality, management ability, earnings and liquidity, are a significant influence on the level of M\&A. One primary influence on these processes would appear to be the perceived compatibility in associational bond and membership.

In conclusion, we note that there is no consistency among authors in what concerns the reasons that lead companies to consolidate through mergers and takeovers.

\section{Reasons for Mergers}

From the perspective of the theory of the firm and the agency theory, there are six underlying reasons for mergers and acquisitions: asymmetric expectations; compensation and tax incentives; replacement costs and market values; seek for economies of scale (and operating synergies management); anticompetitive effects and pursuit of monopoly power; and reducing the risk of insolvency.

\subsection{Asymmetric Expectations}

Myers and Majluf (1984) analyzed the role of information asymmetry in the investment decisions made by firms. The informational asymmetry arises from the fact that administrators hold internal information about the investment opportunities of their company that external investors do not have.

Oliveira (1987) also talks about the possibility of information asymmetry, which postulates that the buyer has information concerning the target company that are not accessible to other market participants and do not reflect on stock prices. Information may be that the price of corporate shares is lower than the real or there are more efficient operational strategies that could be employed by the management of the target company that would result in an increase in stock prices. Thus, it is possible to see the results of the positive abnormal returns to shareholders of the target company as a sign that if someone is interested in acquiring the company, it is because he values the attributes it possesses, but they were undervalued by the market, and prices rise (Oliveira, 1987).

In this line of reasoning, Damodaran (2004) adds that "companies generally have more information about their future prospects than the financial markets." Information asymmetry creates friction when companies try to get resources, as companies with good prospects attempt to distinguish themselves from companies without such prospects, making decisions that are expensive and difficult to imitate (Damodaran, 2004).

\subsection{Compensation and Tax Incentives}

Among the financial motivations for mergers and acquisitions, we can find: use of tax benefits, application of idle funds or saving the bankruptcy costs (Oliveira, 1987). In the same line of reasoning, Ross, Westerfield and Jaffe (1995) add that fiscal and tax incentives make up a reason to carry out mergers and acquisitions since that companies need taxable income to take advantage of possible tax losses. Ross, Westerfield and Jaffe (1995) also elucidate that the tax gains can be a very strong incentive for acquisitions. They list the possible tax gains on a purchase: use of tax losses resulting from operating losses, use of spare capacity of indebtedness, and the use of surplus funds. Nakamura (2005) adds that "in what concerns the other justifications, it could be said that the use of tax benefits seems to be an explanation of restricted scope, both temporal and sectorally".

Damodaran (2004) talks about the emergence of the tax benefits from the merger or acquisition, in order to take advantage of tax laws, and the use of net operational losses to cover profit. Thus, a profitable company acquires a company with operational losses to reduce its tax burden.

The theoretical framework, when treating about companies that earn profits, explains the benefits of compensation and tax incentives as one of the reasons which trigger mergers. But the credit unions have a different form of taxation, because they are non-profit organizations: "the cooperative does not exist to create wealth and then distribute it in proportion to their members' shareholding" (Becho, 2005). In fact, the 
cooperative plays the role of an economic increaser among the partners, becoming a facilitator in their contacts with society and with the market (Andrade \& Neves, 2008).

\subsection{Replacement Cost and Market Values}

To understand the motive "replacement costs and market values", we refer to Brealey and Myers (2006), for whom enterprises can cut costs and increase sales and profits by eliminating inefficiencies. That means that the cost of capital can be reduced from the moment when companies merge, since the cash flows combined are larger than when independent (Ross, Westerfield \& Jaffe, 1995).

To identify an attractive acquiring, companies use Tobin's $q$ as a measure of performance (and value). That ratio was validated as a variable of unquestionable usefulness in different applications in research on the areas of economics and finance, and has enabled a new understanding of phenomena very distinct from each other, such as dividend policy, capital structure and monopoly power of firms (Famá \& Barros, 2000). Tobin's $q$ is defined as the ratio between the market value of a company and the replacement value of its physical assets (Famá \& Barros, 2000).

Ross, Westerfield and Jaffe (1995) teach that when two companies join the variation of their combined values tends to be less than that which would exist if they remained separate, and a reduction in the variability of the values may occur if there is a less than perfect correlation between the values of the two companies.

\subsection{Seek for Economies of Scale (Operational and Managerial Synergies)}

Coase (1937) was the first scholar to identify synergy as a motive for a merger or acquisition; that occurs when the combined assets of two firms operating together create more value than the sum of each one operating alone. According to Weston and Brigham (2000), synergy is the condition in which, after a synergistic merger, the post-merging value exceeds the sum of the pre-merging values of the separate companies.

Oliveira (1987) points out several sources of gains to takeovers, like reduction of costs of production or distribution, which can occur by achieving economies of scale; vertical integration; adoption of more efficient production programs or access to more developed technologies; using existing management team; and asset purchases. All these motivations are often called synergy. He adds that some gains from acquisitions may be due to a combination of several factors which together produce synergies. Damodaran (2004) adds that the synergy "is the potential additional value of combining two companies; it is probably the logical basis most widely and erroneously used for mergers and acquisitions". For him, the synergy, as a motive for mergers and acquisitions, becomes a conflicting point; this is due to the difficulty of identifying its existence and, if it exists, to assess its value.

Ross, Westerfield and Jaffe (1995), based on the classification of additional cash flows, which explains the synergy, conclude that there are four basic categories of possible sources of synergy: increasing revenues, reducing costs, reducing taxes, and decreasing capital cost.

Damodaran (2004) divides synergies into 'operational' and 'financial'. He includes in operational synergies: economies of scale, greater pricing power, combination of different forces and higher growth in new and existing markets. Regarding financial synergies, he points out: combination of a company with cash reserves or cash surpluses, indebtedness capacity and tax benefits.

Oliveira (1987) argues that financial motives for the acquisition include: use of tax benefits, application of idle funds, and saving the bankruptcy costs. Thus, mergers may even increase the market power of the tenderers firms or eliminate administration inefficiencies of the company being acquired.

\subsection{Anticompetitive Effects and Pursuit of Monopoly Power}

Mergers have often been accused of creating monopoly power. The hypothesis of seeking for market power means that companies that perform merger processes aim, usually, increase the prices of their products, benefiting themselves and other companies in the same industry (Oliveira, 1987).

According to Ross, Westerfield and Jaffe (1995), a company can acquire another to reduce competition. In that case, prices can be increased and monopoly profits can be obtained. For the authors, the empirical evidence does not indicate that the increase in market power is an important reason for mergers to occur.

Based on studies that analyzed the performance of stock prices of companies that underwent mergers, Stillman (1983) and Eckbo (1983) reject the hypothesis of market power. Researches show that rival firms do not benefit from higher prices and have no abnormal gains. However, Eckbo's study (1983) concluded that the rival firms of companies who made the merger have positive abnormal returns around the first public announcement. 
In cases of legally challenged mergers, the hypothesis is that it could provide negative abnormal return for the rival firms, when the merger is challenged, because it would mean reducing the possibility of the realization of what presumably comes due to the generation of a greater market power. Eckbo (1983), however, finds positive but statistically insignificant results.

\subsection{Reduction of the Risk of Insolvency}

When an organization realizes that it is headed for bankruptcy, for reasons inherent to bad conditions of their activity, such as the inability to pay its debts, it resorts to the sale of its assets to avoid further losses, and with the help of the acquiring company, to collect the individual assets into a single company. Hence a triggering motive for mergers and acquisitions arises: reduction of the risk of insolvency, which results from the merger of two or more firms with cash flows without perfect correlation.

According to Ross, Westerfield and Jaffe, in the merger of a company with bad debts with a company with no defaults, creditors may have access to the cash flows from both companies (Ross, Westerfield \& Jaffe, 1995). The authors name "co-insurance effect" that mutual guarantee, which makes the debt less risky and more valuable than before. Still in the view of the authors, the effect of co-insurance allows some mergers increase the wealth of creditors by reducing the shareholder wealth.

Dennis and McConnell (1983), however, conclude that the hypothesis of co-insurance is only partially consistent because there is no statistical evidence that the common shareholders of acquiring companies lose or gain.

\section{Methodological Procedures}

In this study, we conducted a descriptive and qualitative research. It can also be classified as ex-post facto, because we investigated credit cooperatives associated to Central Credit Cooperatives of the State of Minas Gerais (Sicoob Cecremge), which have already gone through mergers.

Cecremge presented us 28 cases of mergers. We picked up four of them, based on the following criteria: accessibility to the cooperatives; success in their process of incorporation, as reported by Cecremge Internal Control Board; existence of a history of processes of merger; equity, and to be located in regions of commercial development. Two cooperatives were situated in the Metropolitan Region of Belo Horizonte, one in the city of Cataguases (in the Zona da Mata region of Minas Gerais), and two in the city of Pirapora, in Northern Minas Gerais.

The interviews were conducted with one director of each cooperative and the accountant of one of them, between April and June 2012. Data were also collected from documents provided by the companies (manuals and reports), and from the institutional websites, and additional information were obtained from the person indicated by the CEO. Those procedures contributed to the characterization of the cooperatives surveyed, allowing gathering information about each cooperative's mission and values, their structural and productive characteristics, the history behind their creation, the number of associates and the shareholders equity on the base date of $12 / 31 / 2011$, which corresponded to the ultimate result on the basis of the financial statements. For the interviews analysis, we used the content analysis method, which focuses on testing hypotheses or questions and unraveling the content hidden behind the manifest content (Minayo, 1998).

\section{Results Presentation and Analysis}

To ensure the cooperatives confidentiality we identified them as Cooperative A, B, C and D. The respondents were identified by the codes A1, A2, B1, C1, D1 and D4.

\subsection{Asymmetric Expectations}

In financial literature we observe a debate about asymmetry of information for investment decision of companies, which arises from the fact that the internal administrators possess information on the company's investment opportunities that the external investors do not have (Myers \& Majluf, 1984). Cooperatives have no shares in the capital market, which means that this reason is not identified in their mergers processes.

Oliveira (1987) said that this reason postulates that the buyer has information about the shares of the target company that is not available to other market participants. Therefore, that does not reflect on stock prices. Thus, this can't be pointed out as a triggering factor for the realization of the processes surveyed. However, some respondents said they had used insider information to support the decision of merging:

The sine qua non condition was precisely the report of incorporation between the two cooperatives, a report determining the positive and negative points and the points that would need some precautionary mechanism so that there would be no future problems. [...] (A1) 
In two other cooperatives, we also noticed the use of the information as a facilitator for the evolution of the merger:

We opened the balance sheets transparently, exchanging and analyzing information together. We passed information to them and they gave us information. [...] In addition, the on-line monitoring of Cecremge helped to check the cooperative's main bottlenecks and the major positive points that cooperative had. [...]. All that facilitated the first increase of information exchange about both parties [...]. (B1)

It was peaceful, because those reports, they were made to four hands, it was very transparent. They opened doors for us so that we could know the numbers, which I, for being at the time Coordinator of the Central Supervisory Board, already had access to the information. (C1)

In Cooperative $\mathrm{C}$, however, the information was not significant for the merger. The respondent's report hinted that the process would go on anyway, regardless of the information incorporated, as follows:

The Credi... provided all the documentation, which Coop... didn't do. They did not provide all the documents. But there was a lot of pressure from Cecremge to accomplish this merger, because Coop... needed to be incorporated in face of its situation before the Central Bank, every day more worsened. (D1)

It appears that the data produced by the technical committees of both cooperatives contributed to support the decisions of the corporate boards both of the incorporated and of the incorporator to carry out the process of incorporation. The information was used to predict possible problems which could be brought by the merger, to identify the existence of problems and to map investment opportunities. Thus, the use of information had a crucial importance to the embedding.

\subsection{Compensations and Tax Incentives}

The available finance literature consulted for this study deals mostly with profit-aimed companies, where the benefits of compensation and tax incentives are stimuli to mergers. However, we should recall that cooperatives have a differentiation in their tax system, since they seek no profit (Becho, 2005), and so this topic should be treated taking that condition into consideration.

Regarding compensation and tax incentives, taken as one of the reasons for mergers and acquisitions, respondents reported that they did not obtain compensation or tax gains, as revealed by the findings in Cooperative A:

The tax aspect did not have a material effect, once the entire tax adjustment of each cooperative, it necessarily is included in the monthly income or incorporated into each cooperative's FATES (Social and Educational Technical Assistance Fund) or technically led to the debit retained earnings or expenses of each cooperative. (A1)

Thus, the findings in cases of mergers in credit unions challenge the reasoning of Damodaran (2004) that talks about the emergence of the tax benefits from the merger or acquisition, in order to take advantage of tax laws or of the use of net operating losses to cover profit. Thus, a profitable company would acquire a company with operating losses to reduce their tax burden. In Cooperatives $\mathrm{C}$ and $\mathrm{D}$, the reports showed that there were no fiscal or tributary incentives in the processes. In Cooperative B, one of the respondents reported that there was a tributary gain. The incorporator cooperative benefited from a provision for payment of Service Tax of the merged one, recorded in its financial statements as an obligation to the Treasury, as it appears below:

We observed that the cooperative incorporated had a (more than necessary) provision for the service tax. This value was related to the service tax payment and it was not due. So, we negotiated with the municipal governments of Santa Bárbara and Barão de Cocais and we greatly reduced it. (B1)

\subsection{Replacement of Cost and Market Values}

The literature points out to the possibility of replacement costs and market values (also known as "cost of capital") work as a triggering factor for the completion of the merger and/or takeover. In studies of Brealey and Myers (2006), the discussion turns to replacement costs and market values, to signal that, from the moment firms undertake mergers and/or acquisitions, they seek to cut costs and increase sales and profits by eliminating inefficiencies. In the view of Ross, Westerfield and Jaffe (1995), "the cost of capital can often be reduced when two companies merge because the costs of issuance of securities are subject to economies of scale".

In the cases under study we identified that the incorporated cooperatives showed problems caused precisely by their inefficiency in managing business costs. That deficiency had opened the opportunity to propose the merger, as can be seen in the following statement: 
At the time of incorporation, [...] it needed to increase the working capital because, with the amount of members it kept and the administrative cost it had, it was not enough to cover their outcome. It worked with a negative financial leverage, with a very low contribution margin, which was insufficient to cover their administrative costs. It had two alternatives: to leverage its equity structure or incorporate with another cooperative that had almost the same affinity. (A1)

The respondent's speech shows that the chances of reversing the corporate economic and financial situation were small, due to the existence of high administrative costs, and that to reverse the situation would require time. The merger became the fastest and most effective solution. In this regard, we extracted an excerpt from the Cooperative B interview:

It had sought to market a manager, twice; a manager experienced in the market, but could not succeed with respect to scale. Given the difficulty of increasing the capital base and depending on results not providing return; then, given the difficulty of capital contribution and the difficulty of the result, they saw that they had no alternative. (B1)

In Cooperative C, the interviewed said that it wasn't having satisfactory results, for a cooperative located in a prime spot and with great growth prospects, as we can see in the respondent reports:

The cooperative had to take ownership of a loan management problem, unable to recover. At the request of the Central Bank and of the Central own audit, those credit transactions had to be treated as a loss. That had an impact on shareholders' equity, but the cooperative did not have very good results, although it did not have a lot of damage either. It showed small positive results, but it showed them. (C1)

In cooperative $\mathrm{D}$, what is striking is the reversal of roles early in the process. The incorporator became the incorporated, due to the negative financial situation it had at the incorporation time. The numbers presented by the incorporated one fitted in the risk levels of the Central Cooperative and of the Central Bank, as we see in the following excerpt:

So it was almost a requirement by the Central Bank that Coop ... would be incorporated; it could not afford to be the incorporator due to the problems it was having. So we got a deal, and we turn out to be the incorporator. (D1)

\subsection{Seek for Economies of Scale (Operational and Managerial Synergies)}

The theory that deals with the motives that lead to mergers and acquisitions includes seeking economies of scale (operational and managerial synergies). We identified this motive in Cooperative A:

[...] The motivation that led us to this was really to gain scale. With it, the cooperative was able to increase its customer base, the volume of sales, the turnover, the amount of funding, and the volume of capitalization. (A1)

When referring to economies of scale, the discussion leads to the theoretical literature that concerns also to the discussion about operational and managerial synergies. Oliveira (1987) says that achieving economies of scale can be considered as one of the 'motives' translated by the term 'synergy'.

There was 'synergy' in the merger process of Cooperative A, due to the combination of interests between parties, since, at the same time, the incorporator aimed to increase its operations, and the incorporated started to have greater growth prospects. As seen above, the incorporator believed there would be a growing number of members, an increasing volume of funding and sales (financial results). From the moment, Respondent A2 reported the interest of the incorporator in starting to work in Montes Claros, a city that had only the incorporated cooperative (formed by the workers of a higher education institution), it suggests that the cooperative was benefited by the potential new products, services, etc. In the context of Cooperative B, the respondent made it clear that the main reason for the merger process was gaining scale:

Gain scale, mainly. We had a limited area and we have to understand the following: in order to be attractive to our members, we had to have scale, covering our fixed costs and to be able to have a better condition even better for our members. So it was mainly due to the scale, to gain scale, the main reason of the merger. (B1)

In Cooperative $\mathrm{C}$, this motive was not so visible in the respondent's verbalization. But he said that the incorporator had assessed the positive aspects that the process would add to the incorporator. Some points mentioned in the interview are related to operational synergies:

[..] The cooperative has grown enormously. [...] We had a smashing assets growth, where, in one year, we went from a net worth of $\mathrm{R} \$ 6,000,000.00$ and increased to $\mathrm{R} \$ 12,000,000.00$. Anyway, gains were very impressive, and a permanent and continued growth. (C1) 
We can see the existence of synergy in the speech of one of the respondents in Cooperative D:

It was precisely by the perspective of economies of scale that we made a study here. We found out that we have a long way to go in the three major cities in which we have agency. (D1)

Ross, Westerfield and Jaffe (1995) explain that there are four basic categories of possible sources of "synergy": increasing revenues, reducing costs, lower taxes and decreasing the cost of capital. In the cases studied, we observed that increasing revenues and reducing costs were actually considered to support the incorporation process. Tax cuts and decrease of capital costs were treated separately in this research, because they are considered reasons for mergers and acquisitions. Thus, there is a theoretical framework aimed at these two points.

\subsection{Anticompetitive Effects and Pursuit of Monopoly Power}

Despite being regarded as one of the factors for mergers and acquisitions in the financial literature, the anticompetitive effects and the pursuit of monopoly power do not present empirical evidence of being an important reason for the occurrence of fusions (Ross, Westerfield \& Jaffe, 1995).

We investigate this in the respondents' answers. They were unanimous to declare that this was not an important factor. Instead, we identified a concern to the strengthening of the cooperative system, because if the cooperative incorporated had not had the chance to carry out the process, the backlash could influence other cooperatives in the system. It seems that there was an alliance between these cooperatives, because the respondents reported that the incorporation process exceeded the expectations of turning into just a "business" and became a deal with reciprocal links between the cooperatives involved:

They first looked for us because of the good relationship that we have with the CFO of the time. As I said initially, we study together on a project in Pedro Leopoldo, in a course on cooperatives and we went there together every fortnight to study. So, we had an exchange of information, a mutual help among us. We all worked together and we made a very solid friendship. That facilitated the process. (B1)

One of the findings that draw attention concerns the declaration of an interviewee who reported his concern, at the time, with the situation of the incorporated cooperative. There was, in fact, a harmony of interests, and not a seeking for competitive practices. We recall that Oliveira said that mergers are often accused of seeking monopoly power, which would allow them to increase prices and benefit their own industry (Oliveira, 1987). Oliveira (1987)'s statement can be attributed to mergers and acquisitions between ordinary companies. However, it does not apply to cooperatives, because they pursuit the strengthening the system as a whole. Ordinary companies are always looking for the increase in their competitiveness, and thus they can acquire another company in order to reduce competition. In this regard, we quote a verbalization of the respondent of Cooperative C:

For the incorporator there was no downside. [...] We preserved the cooperative system, with the image of strength that has always been touted by us. Also, we had a resounding growth one year after the merger, because we were able to do a good job in the commercial area of Ubá and region, and we were able to add many new members. (C1)

\subsection{Reduction of Insolvency Risk}

As Kim and McConnell (1977) said, the aim to reducing the risk of insolvency is a triggering factor of the merger process. These authors reported that the possibility of failure is reduced by the combination of businesses, and concluded that the organizations they analyzed had made, after the incorporation process, a greater use of financial leverage.

In Cooperative A, as respondent A1 said, the incorporated cooperative was having problems:

The incorporated cooperative, the Coop..., came with economic and financial results slightly short of its actual need and its proper structuring of costs [...] that was the reason that led to the process. (A1)

Ross, Westerfield and Jaffe (1995) point out that the merger of a defaulted company with a company with no defaults enables creditors to have access to both companies' cash flows. The default situation signaled by Ross, Westerfield and Jaffe (1995) occurs when the company is excessively leveraged and strong with the presence of costly capital. Thus, a merger also means diversification of risk. In the specific case of cooperatives, the members of the incorporated cooperative will have a wider access to credit sources due to the synergy of the merger, and to the increase of the Referential Equity, as they are configured as clients, suppliers and partners at the same time. However, from the moment a cooperative has losses, these are prorated between all partners, due to the responsibility with regard to both the losses presented in their balance sheets as to the commitments made with 
third parties, on the basis of Clause 80 of Law 5.764/71. Regarding Cooperative B, we identified that the incorporated was having negative results (and this fact often entails the extinction of the cooperative). Before this could happen, it chose the incorporation process:

The incorporated company had a small active, around three million; and with small and even negative results, but it had a little Referential Equity (PR); it had a limit, a volume of operations very low, far below the maximum volume of operations per member. (B1)

Cooperative $\mathrm{C}$ had negative results at the time, due to provisions related to loans. We repeat $\mathrm{C} 1$ 's statement:

The cooperative had to take ownership of a loan management problem, which it was unable to recover. At the request of the Central Bank and of the Central own audit, those credit transactions had to be treated as a loss. That caused an impact on the equity. (C1)

With respect to the incorporation of Cooperative D, irregularities were found. It was necessary to apportion the damages to their members, as the interviewee declares:

After the merger, we discovered a fraud, a scam that reached around two million and five hundred, so we had to rectify that. (D1)

Thus, the reason 'reduction of the risk of insolvency' was not identified as a triggering factor in this process.

\section{Final Considerations}

This study investigated the reasons for the mergers undertaken in four credit unions belonging to the Central Cooperative of Minas Gerais (Sicoob Cecremge), trying to check if the underlying reasons arising from the theory of the firm and the agency theory could be identified in credit unions mergers processes. Cooperatives have unique characteristics, such as their organizational form. Then, this study aims to contribute for a better understanding of the processes of mergers, and, perhaps, for the review of organizational processes that may, in fact, optimize future processes of mergers and improve the expansion of these processes in Brazil.

We developed a descriptive, qualitative study, based on a multiple-case study, and we used the method of interview for the collection of the data, which then were treated in the light of the content analysis. Were also used direct observation and document analysis.

The units of analysis of the chosen segment comprised four cooperatives of credit that have undergone processes of mergers from 2008 to 2011 . The research subjects were managers and employees who participated directly in the process, sometimes in the actual negotiations, or in the financial and economic reporting to the boards, and totaled six subjects.

The central focus of the research was to identify, at each credit union researched, the reasons that led to the incorporation, and relate them to the reasons listed in the theoretical framework of the theory of the firm and the agency theory: asymmetric expectations, compensation and tax incentives, replacement costs and market values, seeking for economies of scale (operational and managerial synergies), the anticompetitive effects and pursuit of monopoly power, and the reduction of the risk of insolvency.

Credit unions do not have shares in the capital market, and then asymmetric expectations do not apply in its entirety. However, we observed that insider information were used to attain the decision to merge and the initial information obtained by those involved in the negotiations were crucial to the evolution of the processes.

The replacement cost and market value, or cost of capital, was identified as a factor in three cooperatives. In the remaining one, the incorporator became incorporate. Compensation and tax incentive, anticompetitive effects and search of monopoly power were not motivating factors, but we found search of economies of scales as a motive in all cooperatives studied.

So, compensation and tax incentives, anticompetitive effects and the pursuit of monopoly power have not motivated the decision for the merger, but we found the pursuit of economies of scale as a factor that led to the completion of the merger in all four cases. Finally, we identified also reducing of risk of insolvency as a motive to merger.

Considering the stimulating results we got, we suggest the carrying out of another study to specifically focus the influence of each part listed as an underlying reason for merger in the theory of the firm and in the agency theory. We suggest it to be based on a quantitative work, and precisely dedicated to demonstrate, through indexes applied to the financial statements, if mergers result in an actual improvement in the cooperatives' financial terms. 


\section{Acknowledge}

The authors wish to thank FAPEMIG (Fundação de Amparo à Pesquisa do Estado de Minas Gerais-Research Support Foundation of the State of Minas Gerais) for research funding, as well as the Fellows of Scientific Initiation Christian Moisés Tomaz and Natália Xavier Bueno.

\section{References}

Alchian, A., \& Demsetz, H. (1972). Production, information costs, and economic organization. The American Economic Review, 62(5), 777-795.

Andrade, A., \& Rossetti, J. P. (2009). São Paulo: Atlas.

Andrade, H. C., \& Neves, M. C. R. (2008). Cooperativismo e tributação: um estudo do ramo agropecuário brasileiro. Revista de Contabilidade e Organizações, 2(4), 90-106. http://dx.doi.org/10.11606/rco.v2i4.34723

Becho, R. L. (2005). Tributação das cooperativas. São Paulo: Dialética.

Borges, C. E. A. (2009). Mudança na percepção de valor em cooperativas de crédito pós-aglutinação: um estudo de caso. Master's Thesis, FEAD, Belo Horizonte, MG, Brazil.

Braga, C. F. (2000). Cooperativismo noções. [s.l.], [s. n.].

Brealey, A. R., \& Myers, S. C. (2006). Finanças corporativas: investimento de capital e avaliação. Porto Alegre: Bookman.

Camara, G. A. N. (2007). Fusões e aquisições: análise do desempenho, da performance e da competitividade: estudo de caso do sistema Usiminas. Master Dissertation, CEPEAD, UFMG, Belo Horizonte, MG, Brazil.

Camargos, M. A. (2008). Fusões e aquisições de empresas brasileiras: criação de valor, retorno, sinergias e risco. Doctoral Dissertation, CEPEAD, UFMG, Belo Horizonte, MG, Brazil.

Camargos, M. A., \& Barbosa, F. V. (2003). Fusões, aquisições e takeovers: um levantamento teórico dos motivos, hipóteses testáveis e evidências empíricas. Caderno de Pesquisas em Administração, 10(2), 17-38. São Paulo.

Camargos, M. A., \& Camargos, M. C. S. (2010). Análise da Produção Científica sobre Fusões e Aquisições na literatura Nacional. ENCONTRO DA ASSOCIAÇÃO NACIONAL DE PÓS GRADUAÇÃO E PESQUISA EM ADMINISTRAÇÃO. Rio de Janeiro, RJ, Brasil, 34.

Cano, M. (2002). O recente processo de fusões e aquisições na economia brasileira. Master's Thesis, Unicamp, Campinas, SP, Brasil.

Coase, R. H. (1937). The nature of the firm. Economica, 4(16), 386-405. http://dx.doi.org/10.1111/j.1468-0335.1937.tb00002.x

Damodaran, A. (2004). Finanças corporativas: teoria e prática. Porto Alegre: Bookman.

Dennis, D., \& McConnell, J. J. (1983). Corporate merger and security holder returns: tests of the investment hypothesis, the incentive hypothesis, and the co-insurance hypothesis. Texas: A e M or Purdue.

Eckbo, E. B. (1983). Horizontal mergers, collusion, and stockholder wealth. Journal of Financial Economics, 11, 241-273. http://dx.doi.org/10.1016/0304-405X(83)90013-2

Famá, R., \& Barros, L. A. (2000). Q de Tobin e seu uso em finanças: aspectos metodológicos e conceituais. Caderno de Pesquisas em Administração USP, 7(4), 27-43.

Firth, M. (1980). Takeovers shareholders returns, and the theory of the firm. The quarterly review of economics and finance, Champaign, 94(2), 235-260.

Gilpatrick, K. (2007). Coming together. Credit Union Management, October, 22-26.

Goddard, J., McKillop, D., \& Wilson, J. O. S. (2009). Which Credit Unions are Acquired? Journal of Financial Services Research, 36(2-3), 231-252. http://dx.doi.org/10.1007/s10693-009-0055-x

Hosono, K., Sakai, K., \& Tsuru, K. (2006). Consolidation of cooperative banks (Shinkin) in Japan: motives and consequences. RIETI Discussion Paper Series 06-E-034. Tokyo, Japan: Rieti.

Jensen, M. C., \& Meckling, W. H. (1976). Theory of the firm: managerial behavior agency, costs and ownership $\begin{array}{lllll}\text { structure. Journal of } & \text { Financial 305-360. }\end{array}$ http://dx.doi.org/10.1016/0304-405X(76)90026-X 
Kim, E. H., \& McConnell, J. J. (1977). Corporate merger and the co-insurance of corporate debt. Journal of Finance, 32(2), 349-365. http://dx.doi.org/10.1111/j.1540-6261.1977.tb03275.x

Law n. 4.595, de 31 dezembro de 1964. (1980). Dispõe sobre a Política e as Instituições Monetárias, Bancárias e Creditícias, Cria o Conselho Monetário Nacional e dá outras providências. Diário Oficial da União. Brasília, DF: Casa Civl.

Law n. 5.764, de 16 dezembro de 1971. (1971). Define a Política Nacional de Cooperativismo, institui o regime jurídico das sociedades cooperativas, e dá outras providências. Diário Oficial da União. Brasília, DF: Casa Civl.

Law n. 6.404, de 15 dezembro de 1976. (1976). Dispõe sobre as Sociedades por Ações. Diário Oficial da União. Brasília, DF: Casa Civl.

Lima, R. E. (2008). Desempenho das cooperativas de crédito que se transformaram para a modalidade de livre admissão. Master's Thesis. CEPEAD, UFMG, Belo Horizonte, MG, Brazil.

Minayo, M. C. S. (1998). Fase de análise ou tratamento do material. O desafio do conhecimento: pesquisa qualitativa em saúde. (5th ed., pp. 197-247.). São Paulo: Hucitec.

Myers, S. C., \& Majluf, N. S. (1984). Corporate financing and investiment decisions when firms have information that investors do not have. Journal of Financial Economics, 13(2), 197-221. http://dx.doi.org/10.1016/0304-405X(84)90023-0

Nakamura, A. A. (2005). Desempenho de processos de fusões e aquisições: Um estudo sobre a indústria petrolifera mundial a partir da década de 90. Master's Thesis. Instituto de Economia da UFRJ, Rio de Janeiro, RJ, Brazil.

Oliveira, J. L. (1987). Aquisição de empresas: estudo de um processo de incorporação no setor têxtil. Master's Thesis. FACE, UFMG, Belo Horizonte, MG, Brazil.

Penrose, E. T. (1959). The theory of the Growth of the Firm. New York: Wiley.

Pinheiro, M. A. H. (2010). Cooperativas de crédito: história da evolução normativa no Brasil. $B C B$. Retrieved January 23, 2010, from http://www.bcb.gov.br/MICROFIN

Ross, S. A., Westerfield, R. W., \& Jaffe, J. F. (1995). Administração financeira. São Paulo: Atlas.

Stillman, R. (1983). Examining antitrust policy toward horizontal mergers. Journal of Financial Economics, 11. http://dx.doi.org/10.1016/0304-405X(83)90012-0

Trindade, M. T., Filho, F. de A. F., \& Neto, S. B. (2008). Análise do desempenho financeiro das cooperativas de crédito brasileiras nos últimos 10 anos. ENCONTRO DE PESQUISADORES LATINO-AMERICANOS DO COOPERATIVISMO. Retrieved December 29, 2011, from http://www.bcb.gov.br/?MICROFIN.

Veloso Júnior, E. L. (2011). Estudo do Desempenho de fusões e incorporações entre cooperativas de crédito no Brasil. Master's Thesis. CEPEAD, UFMG, Belo Horizonte, MG, Brazil.

Weston, J. F., \& Brigham, E. F. (2000). Fundamentos da administração financeira. São Paulo: Pearson Makron Books.

Worthington, A. C. (2004). Determinants of merger and acquisition activity in Australian cooperative deposit-taking institutions. Journal of Business Research, 57(1), 47-57. http://dx.doi.org/10.1016/S0148-2963(02)00283-7

\section{Copyrights}

Copyright for this article is retained by the author(s), with first publication rights granted to the journal.

This is an open-access article distributed under the terms and conditions of the Creative Commons Attribution license (http://creativecommons.org/licenses/by/3.0/). 